\title{
Ispovijesti - Augustinov nagovor na filozofiju
}

\author{
Marina Novina*
}

\begin{abstract}
Sažetak
Ispovijesti Aurelija Augustina iznimno su filozofijsko djelo unatoč činjenici da je to određenje često zanemareno. Uvid u strukturu i sadržaj Ispovijesti otkriva još više, da je filozofija bila trajna sastavnica Augustinova života, a stoga što ju razumije kao ljubav prema mudrosti, Augustin i čitatelja nagovara na filozofiju kako bi i on stvorio temelje za confessio te postao istinski ljubitelj Boga. Zaista, originalan je to i vrstan Augustinov odgovor na pitanje: je li Augustin filozof? U tom smislu ovaj rad propituje nekoliko međusobno povezanih aspekata i odgovara na sljedeća pitanja: Možemo li Augustina opravdano smatrati filozofom? Zašto filozofijska dimenzija Ispovijesti ostaje nezamijećena? Kolika je debljina $i$ važnost filozofijskog sloja Ispovijesti? Kakvo je Augustinovo shvaćanja filozofije, kako se ono očituje u kontekstu Ispovijesti $i$ na koji način ih čini Augustinovim nagovorom na filozofiju?

Ključne riječi: Ispovijesti, Aurelije Augustin, filozofija, ljubav prema mudrosti, confessio, nagovor na filozofiju
\end{abstract}

\section{Uvod}

Aurelije Augustin jedan je od najvećih filozofa otačkog vremena i jedan od najznačajnijih teologa Crkve koji je utjecao na cjelokupni crkveni život: filozofiju i dogmatiku, moral i mistiku, ali i društveno-karitativnu dimenziju, politiku i pravo (Augustin, 1983, 351). Još više, Augustinova je misao utjecala i na cijeli niz istaknutih filozofa počevši od Tome Akvinskog pa sve do Gadamera. ${ }^{1}$ Zapravo, kako kaže Mišić:

Poneko izvanredno djelo kadro je pojedinca učiniti junakom dana ili godine, malobrojni su obilježili čitavo stoljeće, a još je manje ljudi za koje se može reći da njihova

* Marina Novina, mag. phil., soc., Fakultet filozofije i religijskih znanosti, Sveučilište u Zagrebu. Adresa: Jordanovac 110, 10000 Zagreb, Hrvatska. E-pošta: marina.novina@ffrz.hr

1 Uvid u Augustinovu važnost za retoriku i filozofiju komunikacije donosi zbornik radova u kojem svako poglavlje iznosi utjecaj Augustinove misli na jednog kontinentalnog filozofa (Edmund Husserl, Martin Heidegger, Jean-François Lyotard, Hannah Arendt, Albert Camus, Hans-Georg Gadamer, Paul Ricoeur i Jacques Ellul) (Troup, 2014, 1). 
djela i misli nadilaze tok vremenske prolaznosti postajući trajno nadahnuće i putokaz. Jedan od takvih iznimnih velikana misli i duha jest Aurelije Augustin (Mišić, 1987, 69).

Stoga su Augustin i njegova djela predmet brojnih istraživanja te o njima danas postoji zaista opširna literatura. Točnije, »bibliografija o Augustinu je ogromna, nedavno je izračunano da se o hiponskom biskupu objavljuje jedna knjiga tjedno« (Moreschini, 2009, 404). To neupitno potvrđuje Augustinovu važnost, ali i aktualnost njegove misli. No, istodobno otkriva da su brojna pitanja još uvijek otvorena. $\mathrm{U}$ jednom povijesnom trenutku, među brojnim pitanjima našlo se i ono je li Augustin samo teolog ili i filozof? Možda, iz raznih razloga, nedovoljno poznato, ali poznavatelji srednjeg vijeka prokazali su to pitanje kao neutemeljeno, a novija istraživanja to potvrđuju te dodatno otkrivaju Augustina kao filozofa i u suvremenom smislu riječi.

Ono što smatramo nedovoljno jasno rečenim to je da je na to i takva pitanja zapravo odgovorio i sam Augustin jednim od svojih najpoznatijih i najčitanijih djela Ispovijesti, koje možemo i moramo smatrati filozofijskim djelom. Dapače, uzmemo li u obzir Augustinovo shvaćanje filozofije, možemo ih smatrati Augustinovim nagovorom čitatelja na filozofiju, kako bi i sam čitatelj stvorio temelje za confessio te postao istinski ljubitelj Boga. No, i određenje Ispovijesti kao filozofijskog djela često je bilo, ako ne upitno onda, ostavljeno po strani. Stoga se ovim radom želi prvo utvrditi možemo li Augustina opravdano smatrati filozofom. Drugo, želi se istražiti zašto se filozofijska dimenzija Ispovijesti često ostavlja po strani. Treće, cilj je predočiti „debljinu“ i važnost filozofijskog sloja Ispovijesti. Četvrto, želi se razumjeti kakvo je bilo Augustinovo shvaćanje filozofije i što ono govori o interpretaciji Ispovijesti kao filozofijskog djela, i još više kao Augustinova nagovora na filozofiju.

\section{Je li Augustin filozof?}

Nekako s razvojem pozitivističkih ideja u 19. stoljeću otvorila se rasprava, među ostalima, i oko pitanja je li Augustin bio filozof ili isključivo teolog, odnosno jesu li njegova djela isključivo teološka. Rasprava je zapravo proizišla iz pitanja može li se u srednjem vijeku uopće govoriti o filozofiji. No, istinski poznavatelji srednjeg vijeka jasno ističu da su takva pitanja odraz nepoznavanja srednjeg vijeka te da su utemeljena na predrasudama o srednjem vijeku. ${ }^{2}$ Naime, poznaje li se vrijeme u kojem je Augustin živio, jasno je da se filozofija i teologija

2 »Riječ je o velikoj Renanovoj tezi (thèse) iz 1852. Averroès et Vaverroüsme latin, u: E. Renan: Oeuvres complètes, Vol. III, Edition définitive établie par H. Psichari, Paris, 1949. Renan vidi cilj razvitka ljudske misli u modernom racionalizmu. Srednji vijek je vrijeme iracionalizma i tisućgodišnjeg prekida kulturne povijesti čovječanstva, a latinski averoizam koji on rekonstruira kao istinsko bezvjersko mišljenje neuspjeli je ali nužni pokušaj slobodnog mišljenja usred jednog bezumnog svijeta. Kasnija istraživanja bjelodano su pokazala svu neutemeljenost i ideološku tendencioznost Renanova pokušaja « (Kušar, 1996, 20). Detaljnije o predrasudama o srednjem vijeku vidi: Janeković-Römer, 2007, 501-508; Hannam, 2009. 
zapravo ni ne mogu proučavati odvojeno. Ne u smislu da jedne ili druge nije bilo, nego da se ne mogu razumjeti jedna bez druge. Dakle, srednji vijek

ima svoje svjetlo te još ne poznaje modernih distinkcija između „skolastike“, „mistike“ i „filozofije“. To je srednji vijek u kojem idejna gibanja nisu odijeljena od organizacije duhovnog života u samostanskim i sveučilišnim središtima niti od prevratničkih događaja u državama i društvima. Vrijeme je to u kojem nastaje autohtona misao slijedeći misli velikih prethodnika jer su mislioci znali da se vlastita misao pravo začinje, rađa i razvija u okruženju misli velikih prethodnika koje se ne oponaša već se s njima stupa u produktivni dijalog. Takva se misao trudi da bez predrasuda razumije također iskustvo religioznog vjerovanja jer je otvorena za sve ono što pokreće čovjeka kao i za sve manifestacije ljudskoga duha uopće « (Kušar, 1996, 8). ${ }^{3}$

Dakle, srednji je vijek vrijeme koje ne poznaje suvremene klasifikacije, i nama je to možda neobično, ali tada je bilo sasvim uobičajeno da su u raspravama pomiješani teološki i filozofijski sadržaji (Copleston, 1989, 55). Stoga, gledamo li Augustina u kontekstu njegova vremena, uopće nije bilo upitno je li on filozof. ${ }^{4}$ No, s obzirom na tu pomiješanost tematika i činjenicu da Augustin nikada zapravo nije izgradio neki filozofski sustav niti definirao ili dokazao svoje ideje i teze na primjerice tomistički način, treba imati na umu da svako izdvajanje „čisto“ filozofijskih aspekta Augustinove filozofije uvijek osiromašuje originalnost Augustinove misli (Copleston, 1989, 56-57). No, zanemariti filozofijske aspekte isto tako značilo bi iskriviti Augustinovu misao. Neki srednji „put razumijevanja“ bio bi dakle poznavati i uvažiti obilježja vremena, ali i Augustinovo razumijevanje filozofije, te u tim okvirima odrediti filozofijske aspekte Augustinove misli i njihovu suvremenost. U prilog takvomu razmišljanju svakako idu istraživanja Augustinovih djela ${ }^{5}$ koja jasno pokazuju da je Augustin pisao djela filozofijske tematike, a govori to i sam Augustin u Ispovijestima ${ }^{6}$ Dapače, u skladu s rečenim, jasno je da su sva Augustinova djela protkana filozofijskom mišlju, ali ono što su istraživanja dodatno istaknula to je da se uočava kako Augustin filozofijskim

3 Dakle, »Na pitanje dakle, je li postojala filozofija u srednjem vijeku, valja odgovoriti potvrdno. Onaj koji je hoće prosuditi treba se osloboditi modernih kriterija za to i nastojati da je upozna i prosudi iznutra, sine ira et studio. Tek nakon toga bit će u stanju donijeti sud o proučenoj misli, dakako, reflektirajući svoje kriterije prosudbe. Uostalom, taj imperativ vrijedi za svaku vrstu povijesnog istraživanja i za bilo koju epohu « (Kušar, 1996, 24).

4 Ipak, neki Augustina smatraju filozofom isključivo u kontekstu njegova vremena. Vidi: Raguž, 2009, 156.

5 Augustinova djela se obično svrstavaju u tri skupine: a) tzv. »dijalozi iz Cassiciacuma« pisani između 386. i 388. kratko nakon »obraćenja«, b) djela »prijelaznog razdoblja« (388.-395.) i c) djela iz vremena biskupovanja (396.-430.). Djela prve dvije skupine su uglavnom filozofijskog karaktera, no sva Augustinova djela pokazuju da se Augustinova filozofijska misao razvijala te da je Augustin, kako su godine prolazile, sve više isticao nedostatnost vlastite filozofijske spekulacije spram vjere, te da je u Retractationes došao do toga da ju je u bitnome nijekao (Moreschini, 2009, 405).

6 Naime od samog Augustina saznajemo da je napisao (381.), inače izgubljenu, raspravu O lijepom i prikladnom (skladnom). Vidi: Augustin, 1983, 75, 77; 4,13. i 4,15. Napomena: Kad citiramo Augustinova djela Ispovijesti i $O$ državi Božjoj te Aristotelovo djelo Nagovor na filozofiju u unutartekstnoj citatnici, uz podatke o autoru, godini izdanja i stranici, donosimo i tradicionalnu referencu na knjigu i glavu odnosno kod Aristotela na redak. 
problemima pristupa na zaista originalan način, blizak suvremenim filozofijskim problematiziranjima. Naime, kako kaže F. Cayre:

ako su filozofijska pitanja kojima se bavio sveti Augustin proučavana na racionalan način i ne samo iz perspektive vjere; 2) ako ta pitanja uključuju glavne probleme koje postavlja svaka filozofija vrijedna toga naziva; 3 ) ako su rješenja koja nudi na njih povezana uobičajenim načelima sposobnima dati cjelini solidnu koherenciju. Ako su ti uvjeti ispunjeni, tada kod svetog Augustina postoji istinska filozofija koja može biti odvojena od teologije, pa čak i ako je on sam nije odvajao (Teske, 2008, 16). ${ }^{7}$

Augustinove Ispovijesti donose brojne primjere Augustinova istinski filozofijskog propitivanja, u kojem, i kada je riječ o pomiješanosti filozofijske i teološke tematike, Augustin traži racionalne odgovore na brojna filozofijska pitanja. Druga je stvar to što u svojim propitivanjima dolazi do zaključka da je za odgovor nužna vjera (ne uvijek i ne za spoznaju svega) ${ }^{8}$ ili da se odgovor nalazi na stranicama Svetog pisma.

\section{Ispovijesti (i njihova slojevitost)}

Ispovijesti su zasigurno najpopularnije Augustinovo djelo. Znao je to već i Augustin koji je pred kraj svojeg života napisao:

Koje je od mojih djela najuspješnije, najbolje poznato i voljeno, ako to nisu Ispovijesti? [Na to Ivan Pavao II dodaje:] Povijest nikad nije proturječila tomu sudu, nego ga je potvrdila. Čak i danas, Ispovijesti sv. Augustina iznimno su čitane, s obzirom na bogatstvo njihova unutarnjeg uvida i vjerskog osjećaja imaju profinjen utjecaj na um muškaraca i žena, smiruju ih i uznemiravaju. To je istinito ne samo za vjernike, nego i za one bez vjere [...] Obraćenje sv. Augustina, čak i u potpunosti dominirano potrebom da se pronađe istina, ima puno toga poučiti muškarce i žene današnjice, koji su toliko često u zabludi o najvažnijim životnim pitanjima (Ivan Pavao II., 1986).

Traganje za istinom (na brojnim razinama) zaista je jedno od temeljnih obilježja Augustinovih Ispovijesti. A upravo traganje za istinom, raskrinkavanje zabluda i lažnih modela koji dominiraju našim mišljenjem kako bi vidjeli što jasnije stvarnost i ono što je ispred nas, u tom smislu i vraćanje na pravi put, zasigurno je dobar pokušaj prikaza barem dijela zadataka filozofa kroz stoljeća (Strawson, 1999, 3). Odgovarali bi ti navodi i onomu što nam Platon poručuje preko tzv. slike špilje u Državi i Aristotelovim određenjima iz Metafizike ili pozivu iz Nagovora na filozofiju. Naime, ukoliko bi to bila zadaća isključivo analitičkog filozofa, naime Strawson (na kojeg smo referirali) pokušava odrediti zadaće analitičkog filozofa, tada je Augustin zaista bio još više originalan i daleko ispred svojeg

7 Napomena: svi prijevodi citata iz literature na stranom jeziku u ovome radu su vlastiti prijevodi autorice članka.

8 Naime, Augustin smatra da postoje i filozofijske istine koje razum može spoznati bez obzira prihvaćao vjeru ili ne, te predmete vjerovanja grupira u tri klase. Postoji ono što se uvijek mora vjerovati i nikada ne može biti shvaćeno (povijesni događaji). Ono što je shvaćeno čim se povjeruje (primjerice matematika) i ono što se prvo vjeruje i poslije razumije (vjerske istine koje se mogu razumjeti jedino čistim srcem) (Teske, 2008, 17-18). 
vremena. »Naravno netko bi mogao odrediti filozofiju tako da bi Augustinova misao bila automatski isključena. Ali svaka takva definicija bi, mogla iz okvira filozofije izbrisati djela Hegela i Akvinca, Kierkegaarda, pa čak i Descartesa « (Teske, 2008, 18).

No, Ispovijesti su se glede određenja (i) kao filozofijskog djela suočile i s poteškoćom jedne druge vrste, a koja je posljedica onoga što može uočiti zapravo svatko. Naime, Ispovijesti su »djelo koje je istodobno autobiografija, filozofija, teologija, misticizam i poezija, djelo u kojem oni koji žeđaju za istinom i poznaju vlastite granice uvijek otkriju sami sebe« (Ivan Pavao II., 1986). Naime, upravo su slojevitost djela i popularnost drugih slojeva (i spomenuto nepoznavanje Augustinova vremena) razlozi da filozofijski aspekti Augustinovih Ispovijesti često bivaju zanemareni, tek natuknuti. Ako se i interpretiraju, ta je interpretacija svedena isključivo na vid utjecaja neoplationizma na Augustinovu misao, a tako se propušta uočiti sva originalnost i dubina Augustinove filozofijske misli (Troup, 2014, X). Naravno, ne možemo propustiti uočiti da dio odgovornosti leži i na filozofima koji su propustili dovoljno jasno istaknuti filozofijski sadržaj i važnost Ispovijesti, i za razumijevanje Augustina kao filozofa i za samu filozofiju.

Ovdje ne možemo govoriti o obilježjima svih istaknutih slojeva Ispovijesti, ali treba uočiti da je slojevitost Ispovijesti prepoznatljiva i na sadržajnoj i na strukturalnoj razini. Naime, gledane u cjelini, Ispovijesti su podijeljene na trinaest knjiga, a među ostalim su autobiografija kronikalnobiografske i konfesionalne dimenzije. ${ }^{9}$ I jedno i drugo obilježje višestruko je važno za razumijevanje djela. Dakle, s jedne strane Augustin donosi kronološki prikaz najvažnijih životnih događaja, te u tom smislu djelo možemo podijeliti na dva dijela: na vrijeme prije obraćenja i na vrijeme nakon obraćenja. O vremenu prije obraćenja govore knjige 1-7, s time da 7. knjiga (koja je filozofijski gledano najdetaljnije sastavljena) predstavlja intelektualnu prekretnicu u vezi s prihvaćanjem kršćanstva. O samom obraćenju i vremenu nakon obraćenja govore preostale knjige. No knjige 8-13 možemo dalje podijeliti na knjige 8-9 koje, među ostalim, govore o Augustinovu obraćenju i krštenju, a knjige 10-13 razlikuju se od ostalih knjiga na više razina. Prvo, Augustin se iz prošlosti prebacuje u sadašnjost (desete godine nakon obraćenja, tj. 397.). Drugo, preostale knjige Ispovijesti više nisu posvećene Augustinovu životu, nego filozofijsko-teološkim tematikama. Mogućnost takve podjele Ispovijesti nije bila bez posljedica. To govori činjenica da su se tijekom povijesti Ispovijesti (i komentari na Ispovijesti) često tiskale u skraćenoj verziji (uglavnom knjige 1-9) ${ }^{10}$ ispuštajući neke od posljednjih knjiga. Posljedicu tog skraćivanja za određenje Ispovijesti i kao filozofijskog djela nije teško odgonetnuti.

Uz to konfesionalna dimenzija Ispovijesti, očita već iz samog naslova djela, druga je iznimno važna dimenzija za razumijevanje cijelog djela. Ona određuje

9 Temu Autobiografski diskurs u Ispovijestima Aurelija Augustina obradila je 2015. Anita Pavlović u završnom radu na preddiplomskom studiju hrvatskog jezika i književnosti na Sveučilištu J. J. Strossmayera u Osijeku pod mentorstvom doc. dr. sc. Marice Liović. Rad je dostupan na: https:// repozitorij.ffos.hr/islandora/object/ffos\%3A136/datastream/PDF/view

10 Primjere za to nalazimo i među stranim i među domaćim izdanjima. 
strukturu svih knjiga i ujedno predstavlja jedan od Augustinovih razloga pisanja djela. Naime, sve knjige Ispovijesti započinju i završavaju s conffesio. No, kako saznajemo od Augustina u desetoj knjizi, termin confessio za njega ima dvostruko značenje. Confessio je (po)hvala Bogu (ispovijest vjere), za koju je najprimjereniji izraz sama Božja riječ, pa su stoga Ispovijesti protkane brojnim svetopisamskim citatima, a samo djelo jedna je velika pohvala i priznanje Boga. No, confessio je $\mathrm{i}$ ispovijed grijeha, odnosno vid hvale u kojem biće prepoznaje da postoji odmak između čovjeka i Boga, koji je ujedno uvjet mogućnosti za hvalu. Pa stoga J. L. Marion kaže da:

Augustin ne prikazuje samo svoj put prema »confessio«, nego želi uvući i čitatelje u isti »confessio«, želi ih potaknuti na isti »intellectus« $\mathrm{i} »$ affectus« za Boga. Drugim riječima, Augustin ne prepričava svoj život sa svoga gledišta, već s gledišta Boga. U tom smislu u središtu Ispovijesti je Bog i Božje gledište Augustinova života, a ne njegov ego. Stoga se, prema Marionu, kod Ispovijesti uopće ne radi o autobiografiji. Eventualno bi se one mogle nazvati heterobiografijom, dakle biografijom prema Božjem gledu. [...] Snaga se Augustinovih Ispovijesti krije upravo u tomu što u njima ego i drugi prestaju biti mjerodavni, odnosno dolaze na ono mjesto gdje ih očekuje Bog i njegova ljubav. Ispovijesti tako potiču čitatelja da se počinje promatrati i samodefinirati s gledišta Boga (Raguž, 2009, 155-156).

Tako nas slojevitost Ispovijesti upućuje na nekoliko značajnijih detalja. Naime, sve navedeno, od predrasuda o srednjem vijeku do strukture i slojevitosti djela, zasigurno je pogodovalo tomu da se Ispovijesti promatraju u prvom redu kao iznimno vrijedno književno djelo, zatim kao autobiografija, pa kao duhovna literatura, mistika, zatim teološko djelo, da se primijeti i njegova suvremena psihologijska dimenzija, ali da se po strani ostavi njegova filozofijska dimenzija. Ipak, detaljniji pregled sadržaja i strukture Ispovijesti otkriva da je, iako su uglavnom knjige 10-13 prepoznate kao one filozofijsko-teološkog sadržaja, zapravo u cijelo djelo utkan bogat i zanimljiv „filozofijski sloj“. On otkriva Augustina kao originalnog filozofa, govori o Augustinovu razumijevanju filozofije kao pretpostavci i preduvjetu istinskog confessio. Na temelju toga možemo zaključiti da su Ispovijesti i iznimno filozofijsko djelo, ali još više, i Augustinov nagovor čitatelja na filozofiju.

\section{3. „Filozofijski sloj“ Ispovijesti}

Iako nedovoljno prepoznato ili isticano, bogatstvo i zanimljivost filozofijske problematike koju Augustin otvara, na koju upućuje ili je problematizira u $I s$ povijestima nije nestala. Naime, analiza sadržaja Ispovijesti, od prve do zadnje knjige, gotovo iznenadi količinom filozofijskih tema i pitanja koje Augustin stavlja pred čitatelja. Ispovijesti se tako pokazuju kao iznimno filozofijsko djelo bogatog filozofijskog sloja, koji otkriva da je filozofija bila neizostavna sastavnica Augustinova življenja, a Augustin originalan i vrstan filozof. Koliko je „debeo“ filozofijski sloj Augustinovih Ispovijesti možda se najbolje može predočiti apstrahiranjem niza koncepata i pitanja kojima se Augustin posvećuje na više razina 
u Ispovijestima. Dakle, u Ispovijestima Augustin, filozofijski gledano, govori na metafizičkoj, epistemološkoj, etičkoj, odgojnoj i jezičnoj razini. Među temama koje problematizira nalazimo sljedeće: Bog, čovjek, odgoj, duša, ljubav, sloboda, slobodna volja, sreća, jezik, znanje, sumnja, istina, vjera, zlo, pamćenje, sjećanje, vrijeme, prostor, stvaranje itd.

Zapravo nemoguće je ukratko iznijeti sve teme i prikazati sve filozofijski relevantne komentare koje je Augustin utkao, spretno postavio na prava mjesta u kontekst djela i razvio na raznim filozofijskim razinama kroz svih trinaest knjiga Ispovijesti. To može zorno predočiti pregled filozofijskih tema i pitanja kako ga nalazimo u nekoj od knjiga. Za primjer možemo uzeti prvu knjigu ${ }^{11}$ u kojoj se možda, s obzirom na kronikalnobiografsku strukturu djela, najmanje očekuje filozofijski sadržaj. Naime, činjenicu da govori o svojoj najranijoj dobi Augustin koristi da pokaže svu svoju filozofijsku originalnost i domišljatost te već s prvim redcima Ispovijesti otvara cijeli niz tema koje možemo podijeliti u najmanje četiri skupine. Metafizička pitanja: pitanje mogućnosti govora o Bogu, pitanje određenja Božje naravi i konstatacija uređenosti svijeta (Augustin, 1983, 7-9: 1,1-1,4). Etička i pitanja filozofije odgoja: temeljna obilježja odnosa Boga i čovjeka (jedan od Augustinovih temeljnih filozofijskih interesa), određenje konačne svrhe ljudskog života i pitanja filozofije odgoja, od sadržaja do forme i važnosti odgoja. ${ }^{12}$ Epistemološki problemi: razlikovanje između znanja i razumijevanja, između vjere i znanja, razlikovanje vrsta znanja (Augustin, 1983, 7, 10-13: 1,1; 1,6). Pitanja filozofije jezika: odnosa znanja i jezika, razumijevanja i jezika, razuma i jezika, odgoja i jezika, pitanje sadržaja jezika, tj. naravi jezika (Augustin, 1983, $10-13,15: 1,6 ; 1,8)$.

Dakle, debljina „filozofijskog soja“ Ispovijesti tolika je da svaka tema i svaka od trinaest knjiga Ispovijesti mogu i trebale bi biti predmet zasebne analize. No već pregled filozofijskih tema i pitanja, uvid u neke od „filozofijskih detalja“, koje možemo pronaći u Ispovijestima, otkrivaju Augustinovu originalnost. Ipak, ne bi trebalo pomisliti kako je riječ o nekim elementarnim detaljima, jer kako je Strawson uočio: »Ne postoji nešto takvo kao što je elementarna filozofija. Filozofski bazen nema plićaka« (Strawson, 1999, VII). Ono što je važno, a što možemo zaključiti iz načina na koji je Augustin Ispovijesti protkao filozofijskim temama te ih spretno razvijao kroz knjige, činjenica je da je to i Augustin dobro znao. U tom smislu Ispovijesti se mogu i moraju shvatiti kao iznimno filozofijsko djelo. No, još više, baš zato jer zna da filozofijski bazen nema plićaka, Augustin i čitatelja nagovara na filozofiju.

11 Za jasnije razumijevanje savjetujemo pročitati prvu knjigu Ispovijesti.

12 »I hvaliti te želi čovjek, sićušan djelić tvoga stvorenja [...]. Ti ga potičeš da traži radost hvaleći tebe, jer si nas stvorio za sebe, i nemirno je srce naše dok se ne smiri u tebi« (Augustin, 1983, 7: 1,1). Vidi i: Augustin, 1983, 17-28: 1,9-1,20. 


\section{Augustinov nagovor na filozofiju}

Na samom početku, već u trećoj knjizi Ispovijesti čitamo kako se Augustin susreo s filozofijom, kako je filozofija promijenila njegov život i kako ju je on razumio:

Po uobičajenom već redu učenja dođoh do knjige nekoga Cicerona čijem se jeziku gotovo svi dive više nego srcu. Ali ona njegova knjiga sadrži poticaj na filozofiju i zove se Hortenzije. Ali ta knjiga promijeni moja čuvstva i k tebi samome Gospodine, okrenu molitve moje, a želje i čežnje moje učini drugačijima. Odjednom mi omrznu sva isprazna nada te sam stao žudjeti za besmrtnom mudrošću nevjerojatnim žarom srca svoga, i počeo sam se dizati da se vratim k tebi. Nisam, naime, tu knjigu čitao da izoštrim jezik, a samo za to sam, činilo se, trošio majčin novac; bio sam u devetnaestoj godini života, a otac mi je bio umro prije dvije godine; nisam dakle tu knjigu čitao da izoštrim jezik niti je ona na me djelovala stilom, nego sadržajem (Augustin, 1983, 48-49: 3,4).

Nekoliko redaka dalje Augustin potvrđuje ono što pokazuju i istraživanja: »A ljubav prema mudrosti grčki se zove 'filozofija', i njom me je zagrijavala ona knjiga« (Augustin, 1983, 49: 3,4). Dakle, Augustin je filozofiju, na tragu u prvom redu Cicerona, ali i grčkih filozofa, ${ }^{13}$ smatrao ljubavlju prema mudrosti, a istinskim filozofima smatrao one koji ljube mudrost. Kako kaže Augustin: »ono me razmišljanje pobuđivalo, raspaljivalo i zagrijavalo da ljubim, da tražim, da steknem, da posjedujem i da čvrsto zagrlim ne ovu ili onu struju, nego samu mudrost, ma kakva ona bila « (Augustin, 1983, 49: 3,4). Ispovijesti nam otkrivaju da susret s filozofijom nije bio samo jedan trenutak, nego početak traganja za istinom koji će obilježiti čitav Augustinov život. Uvid u sadržaj i strukturu Ispovijesti to jasno potvrđuje. Sve knjige Ispovijesti prožete su brojnim i važnim filozofijskim pitanjima na koja Augustin traži odgovor, istinu, ma kakva ona bila.

U tom smislu, nije neobično da se smatra kako je za Augustina filozofija bila toliko važna da se u Augustinovu životu može govoriti o dva obraćenja, o onom na filozofiju i o obraćenju na kršćanstvo. Ipak, po tom pitanju Bodrožić dobro primjećuje da:

bi obraćenje na kršćanstvo bilo logički nastavak prvoga i dolazak na cilj svih Augustinovih traženja. Ako bi možda bilo pretjerano govoriti o dva obraćenja — jer se radilo o istom procesu u kojem je filozofija odigrala značajnu ulogu da mladi Augustin bolje razumije kršćanstvo - ipak se ne može zanijekati važnost filozofije u njegovoj intelektualnoj formaciji. Ako mu je kršćanstvo predstavljalo puninu, onda mu je filozofija predstavljala značajnu dionicu puta pridonoseći jasnijem poimanju Boga, te razumijevanju mnogih filozofskih pitanja koja do tada nije shvaćao (stvoreni svijet, zlo, duša) (Bodrožić, 2007, 582).

13 Dobro je poznato da je Augustin bio upoznat ne samo s Ciceronom, nego sa širom filozofijskom tradicijom te da je na njegova filozofijska promišljanja utjecao cijeli niz autora: Seneka, Varon, Apulej, Platon, Aristotel, naučavanja manihejaca, neoplatonistički spisi, Plotin, Porfirije itd. Detaljnije vidi: Moreschini, 2009, 405-417. 
No, zahvaljujući Ispovijestima, koje su u tom smislu možda i jedinstven slučaj u povijesti, imamo priliku vidjeti da filozofija nije bila samo bitna dionica puta, nego trajna sastavnica Augustinova življenja. Ljubav prema mudrosti i traganje za istinom prožimaju čitav Augustinov, život pa i sve stranice Ispovijesti. ${ }^{14}$

Stoga je, možemo se složiti:

zapravo, neispravno u intelektualnom tijeku ovog mislioca tragati za nekim odijeljenim filozofskim i teološkim stupnjevima, jer je, kako to i Robert Russell ističe »Augustin napredovao u poznavanju filozofije i teologije pari passu, oblikujući tako originalnu i veličanstvenu sintezu vjere i razuma koja se s pravom karakterizira kao kršćanska mudrost «. U toj sintezi Augustin je vremenski i normativni primat dao vjeri, ne zbog fideizma (o kom kod Augustina ne može biti ni govora) nego zato što temeljna istina do koje čovjek može doći nije plod racionalnog uvida, nego intuicije u neposrednu danost vlastite samoizvjesnosti [...] Razumu je dodijeljena značajna, iako tek uloga pomoćnika i snažitelja vjere kad se ova pomuti, kad se pokoleba. Filozofija, dakle, Augustinu bijaše sredstvo, a ne cilj, a njezina eudajmonistička uloga ostvaruje se kroz blaženstvo u koje čovjeka dovodi kroz filozofiju ostvarena veza s Bogom kao najvišim Dobrom (Bićanić, 1983, 383).

Zapravo, s obzirom na to da su Ispovijesti prožete brojnim filozofijskim temama, da su najznačajniji i prijelomni trenutci Augustinova života bili obilježeni dubokim filozofijskim propitivanjima, od razočarenja u maniheizam u petoj knjizi, prijelomne točke obraćenja u sedmoj knjizi i svih filozofijsko-teoloških tematika posljednjih knjiga Ispovijesti, sasvim je očito da je za Augustina filozofija bila način života, baš kao za većinu grčkih filozofa. Kako kaže A. H. Armstrong:

filozofija je bila sveobuhvatan i iznimno zahtjevan način života, koji je zasigurno zahtijevao, intenzivan studij cijele stvarnosti, ali je vodio, ne samo onome što bi mi zvali 'intelektualnim' ili 'znanstvenim' razumijevanjem prirode stvari, već do razvijanja ljudske dobrote, koja se sastojala u mudrosti, u transformirajućoj mudrosti, koja jedina čovjeku može donijeti dobro-bit (Teske, 2008, 8).

Srž te „dobro-biti“ na koncu se nalazi zapravo u istini, koja jedina može istinski usrećiti čovjeka. U tom smislu važnost i ulogu filozofije za Augustina lijepo predočava jedno Augustinovo razmišljanje iz pete knjige Ispovijesti, iz trenutka kada se Augustin razočarao u manihejca Fausta. Naime, čitamo:

Dakle, kad je došao, našao sam u njemu čovjeka mila i ugodna u govoru, koji je upravo one stvari koje oni običavaju govoriti mnogo slađe raspredao. Ali što je za moju žeđu značio najkrasniji peharnik s dragocjenim čašama? Već su moje uši bile zasićene takvim stvarima, i nisu mi se zato činile bolje što ih je on bolje pripovijedao, niti zato istinite što su bile govornički dotjerane, niti je on zato bio mudra glava što je imao skladno lice i krasan govor. Oni pak koji su mi ga obećavali nisu bili dobri suci, i zato se njima činio razborit i mudar jer ih je zabavljao svojim govorom.

14 Osim Ispovijesti u prilog tomu govore i podatci prema kojima je Augustin iz leksičke obitelji od osam termina koji se u latinskom odnose na filozofiju koristio pet termina. Nešto više od 100 pojavljivanja tih termina nalazi se u ranim Augustinovim spisima (prva skupina), tek nekoliko ih se pojavljuje u srednjem razdoblju, a ostalih gotovo 500 pojavljivanja je iz vremena Augustinova biskupovanja (Catapano, 2016, 719). 
Poznavao sam i drugu vrstu ljudi, koji i istinu smatraju sumnjivom i neće uz nju pristajati ako im se iznosi u kićenu i bujnu govoru. Mene si pak već bio poučio, Bože moj, na divan i tajanstven način, i zbog toga vjerujem da si me ti poučio jer je to istina, a nema drugoga učitelja istine osim tebe, gdje god i odakle god ona sinula. Već sam dakle bio naučio od tebe da ne treba po tome suditi da se nešto istinito govori jer se govori rječito, kao ni to da je nešto lažno zato što riječi s usana ne teku skladno; ali opet ne treba ni smatrati nešto istinitim zato što se iznosi nedotjerano, a nešto lažnim jer je govor sjajan; nego treba znati da su mudrost i ludost nešto kao jela korisna i beskorisna, a riječi kićene i nekićene kao posude gradske i seoske, u kojima se mogu poslužiti jedna i druga jela (Augustin, 1983, 90-91: 5,6).

U kontekstu tog kratkog, ali nadasve značajnog razmišljanja, Augustin, osim niza pitanja koje bi u svojem kontekstu postavila i suvremena filozofija jezika, istodobno govori o pitanju odnosa filozofije i teologije, o temi koja je bila osobito važna i aktualna u trenutku susreta kršćanstva s poganskom filozofijom. Kroz tih nekoliko redaka Augustin, osvrćući se na kritike onih koji su odbacivali sve što nije bilo kršćansko, zapravo jasno govori i o važnoj ulozi filozofije kao ljubavi prema mudrosti koja čovjeka potiče da promišlja, da se ne zaustavlja na površini „stvari“, nego ponire do sadržaja, do istine, pozivajući tako kršćane da se bez straha susretnu s filozofijskom mišlju, jer čovjek prema Augustinu treba poštivati želju za znanjem. ${ }^{15}$ Tako istodobno Augustin anticipira misao sv. Tome, prema kojoj nije važno od koga istina dolazi, nego je važna istina, odnosno filozofija ako je filozofija nužno dovodi do Istine.

Tu misao ponovno nalazimo u sedmoj knjizi Ispovijesti, gdje Augustin preko platonističkih ideja dolazi do spoznaja Boga: »I ja dođoh k tebi između pogana i uperih pogled na zlato što si htio da ga tvoj narod ponese iz Egipta, jer je bilo tvoje gdje god je bilo« (Augustin, 1983, 143: 7,9). Zapravo, kako vidimo, Augustina je ljubav prema mudrosti dovela do nove razine spoznaje da je »nepromjenjiva i istinita vječnost istine iznad moga promjenljivoga duha « (Augustin, 1983, 148: 7,17). U tom smislu filozofiju možemo prepoznati kao preduvjet i temelj za confessio. Naime, ljubav prema mudrosti nužno vodi do spoznavanja sebe samoga (duše) i do spoznaje istinskog podrijetla (Boga) (Teske, 2008, 10). Tako, na kraju, kako je još Aristotel istaknuo: »svi koji se dotaknu razboritosti i mogu kušati tu stvar misle da /sve/ drugo nije ništa [...] od onog što je naše, jedino se to čini besmrtnim, jedino to božanskim« (Aristotel, 1996, 135, 137; B100, B108), uvidio je to i Augustin, kojega je upravo ta ljubav dovela do zaključka da »ako je mudrost Bog, po kojem je načinjeno sve [...] istinski filozof ljubitelj je Boga« (Augustin, 1982, 541: 8,1). Što bi tada bilo poželjnije od nagovoriti čitatelja da se odvaži na filozofiju. 


\section{Zaključak}

Najbolji odgovor na pitanje, oko kojeg su se vodile brojne rasprave, je li Aurelije Augustin bio filozof, ostavio nam je sam Augustin svojim najpoznatijim djelom, Ispovijestima. Cilj ovoga rada bio je pokazati da su Augustinove Ispovijesti uistinu izvrstan odgovor na to pitanje. Ne samo da su iznimno filozofijsko djelo, nego još više - Augustinov nagovor čitatelja na filozofiju kako bi i on sam postavio temelj za confessio te u konačnici postao istinski ljubitelj Boga.

No, činjenica je da se određenje Ispovijesti (i) kao filozofijskog djela često stavljalo u pitanje. U tom smislu utvrđeno je (1) da se Augustina može opravdano smatrati filozofom, i u kontekstu njegova vremena jer je teologija pretpostavljala filozofiju i jedna se bez druge zapravo ne mogu razumjeti, ali i u suvremenom smislu jer je Augustin obradio većinu relevantnih filozofijskih tema istom „metodom“ kao i njemu suvremeni filozofi. Ispovijesti su odlična potvrda tog zaključka. Naime (2) uistinu se može reći da je iznimna slojevitost Ispovijesti dodatni razlog da filozofijska dimenzija djela ostaje gotovo nezamijećena. No, uvid u strukturu i temeljna obilježja djela otkriva da je za Augustina filozofija bila trajna životna sastavnica bez koje se ne može razumjeti ni Augustin i njegova djela. Uz to, (3) prožetost Ispovijesti gotovo svim važnijim filozofijskim temama (primjerice Bog, duša, čovjek, svijet, sreća, ljubav, znanje, istina) na metafizičkoj, epistemološkoj, etičkoj, odgojnoj, jezičnoj razini otkriva velik i bitan debeo i dubok filozofijski sloj Ispovijesti te ih stoga možemo i moramo smatrati iznimnim filozofijskim djelom. Ali, uz to (4), Augustinovo shvaćanje filozofije kao načina života i ljubavi prema mudrosti koja traži i koja je spremna prihvatiti istinu kakva god da ona jest, ljubavi prema mudrosti koja je Augustina dovela do confessio, zaista otkriva Ispovijesti kao nagovor čitatelja na filozofiju, poziva ga da spozna značenje confessio, da postane filozof, tj. istinski ljubitelj Boga.

\section{Literatura:}

Aristotel (1996). Nagovor na filozofiju. Zagreb: Naprijed.

Augustin, Aurelije (1983). Ispovijesti. Zagreb: Kršćanska sadašnjost.

Augustin, Aurelije (1982). O državi Božjoj: Svezak prvi. Zagreb: Kršćanska sadašnjost.

Bićanić, Nikola (1983). Teologija i filozofija sv. Augustina. Crkva u svijetu, 18 (4), 382-387.

Bodrožić, Ivan (2007). Augustinov hod od ljubavi prema filozofiji do filozofije ljubavi. Filozofska istraživanja, 27 (3), 581-593.

Catapano, Giovanni (2016). Philosophia. U: Robert Dodaro, Cornelius Mayer i Christof Müller (ur). Augustinus-Lexikon: Vol. 4 (str. 719-742). Basel: Verlag.

Copleston, Frederick (1989). Istorija filozofije: srednjovekovna filozofija. Beograd: BIGZ.

Hannam, James (2009). God's Philosophers: How the Medieval World Laid the Foundations of Modern Science. UK: Icon Books.

Ivan Pavao II. (1986). Augustinum Hipponensem. U: La Santa Sede. URL: http:// w2.vatican.va/content/john-paul-ii/en/apost_letters/1986/documents/hf_jp-ii_ apl_26081986_augustinum-hipponensem.html (03.08.2017.)

Janeković-Römer, Zdenka (2007). Mnoga lica i značenja srednjovjekovlja: baština prošlosti i suvremeni identitet. U: Ivan Koprek (ur), Thesaurus Archigymnasii: Zbornik ra- 
dova u prigodi 400. godišnjice Klasične gimnazije u Zagrebu 1607-2007 (str. 501-508). Zagreb: Klasična gimnazija u Zagrebu.

Kušar, Stjepan (1996). Srednjovjekovna filozofija. Zagreb: Školska knjiga.

Moreschini, Claudio (2009). Povijest patrističke filozofije. Zagreb: Kršćanska sadašnjost.

Mišić, Anto (1987). Tisućušestota obljetnica obraćenja sv. Augustina. Obnovljeni život, 42 (1), 69-74.

Raguž, Ivica (2009). Biti ljubljen ili ne biti ljubljen — to je pitanje Jean-Luc Marion o sv. Augustinu. Diacovensia, 16 (1-2), 151-171.

Strawson, Peter F. (1999). Analiza i metafizika: uvod u filozofiju. Zagreb: KruZak.

Teske, Roland J. (2008). To Know God and the Soul: Essays on the Thought of Saint Augustine. Washington: The Catholic University of America Press.

Troup, Calvin L. (ur). (2014). Augustine for the Philosophers The Rhetor of Hippo, the Confessions, and the Continentals. Waco: Baylor University Press.

\section{Confessions - Augustine's Protreptic}

Marina Novina*

\section{Summary}

The Confessions of Aurelius Augustine is exceptionally multi-layered, and so its philosophical dimension often goes unnoticed. However, upon immersing ourselves in the content and structure of the Confessions, we find it to be an outstanding philosophical work permeated by all manner of philosophical topics (eg. God, the soul, man, the world, happiness, love, knowledge, truth, etc.) on the metaphysical, epistemological, ethical, educational and linguistic levels. Moreover, a classification of philosophical topics and questions reveals that philosophy was an enduring component of Augustine's life, and since he understood it to be the love of truth, Augustine appears to be exhorting the reader to philosophy in order that the reader might also devise a basis for a confessio and thus become a true philosopher, or rather a person enamoured of God. Thus, we may consider the Confessions to be Augustine's exhortation to philosophy, but also his original answer to the question: is Augustine a philosopher? That he was a philosopher is substantiated by the fact that in his time it was held that theology presupposes philosophy and that indeed, when seen in this context, one cannot be understood without the other. Furthermore, Augustine may be regarded as a philosopher also in terms of contemporary thought. Namely, he dealt with the majority of pertinent philosophical topics using the same „method" as do contemporary philosophers. Insight into the content and structure of the Confessions superbly affirms this conclusion. Thus we can say that the Confessions reveal the originality, topicality and significance of Augustine's thought in regard to this ancient, but always new, quest for truth and so undoubtedly also for contemporary philosophical-theological discussion.

Key words: Confessions, Aurelius Augustine, philosophy, love of wisdom, confessio, exhortation to philosophy

* Marina Novina, mag. phil., soc., Faculty of Philosophy and Religious Studies, University of Zagreb. Address: Jordanovac 110, 10000 Zagreb, Croatia. E-mail: marina.novina@ffrz.hr 